\title{
Manufacture and Utilization of Cassava Flour
}

$$
\text { By }
$$

Udeni Indika Kumarasinghearachchi

Thesis submitted to the University of Sri Jayewardenepura as the partial fulfilment requirement for the award of the degree of

\section{Master of Science}

in

Food science and Technology

2008 


\section{Declaration}

The work described in this thesis was carried out by me under the supervision of Dr. K.K.D.S.Ranaweera, Co-ordinator /Food Science \& Technology Postgraduate Programmes, Department of Food Science and Technology and Prof. A. Bamunuarachchi, Professor of Applied Chemistry, Department of Food Science and Technology and a report on this thesis has not been submitted in whole or in part of any university or any other institution foranother degree.

Udeni Indika Kumarasinghearachchi

Date:. 15-0.3-2009 
We certify that the above statement made by the candidate is true and that this thesis is suitable for submission to the university for the purpose of evaluation.

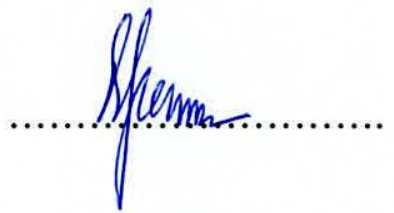

Dr.K.K.D.S. Ranaweera,

Co-ordinator,

Food Science \& Technology

Postgraduate Programmes,

Department of Food Science and

Technology,

University of Sri Jayewardenepura,

Gangodawila,

Nugegoda.

Date:
Prof. A. Bamunuarachchi,

Professor of Applied Chemistry,

Department of Food Science and

Technology,

University of Sri Jayewardenepura,

Gangodawila,

Nugegoda.

Date: 
Affectionately dedicated to my dear parents and two sisters. 


\section{Table of contents}

$\begin{array}{lr}\text { Table of contents } & \text { Page } \\ \text { List of tables } & \text { I } \\ \text { List of figures } & \text { VIII } \\ \text { List of plates } & \text { IX } \\ \text { Acknowledgement } & \text { X } \\ \text { Abstract } & \text { XI }\end{array}$

$\begin{array}{lll}\text { CHAPTER } 1 & 1\end{array}$

INTRODUCTION 1

1.1 Introduction 1

1.2 Objectives 3

$\begin{array}{lll}\text { CHAPTER } 2 & 4\end{array}$

REVIEW OF LITERATURE 4

2.1 Cassava 4

2.1.1 Background on Cassava 4

2.1.2 Cassava plant 4

2.1.3 Root tubers of cassava $\quad 5$

2.1.4 Cassava in the human diet 5

2.1.5 Nutritional value of cassava 6

$\begin{array}{ll}\text { 2.1.6 Cassava products } & 8\end{array}$

2.1.6.1 Cassava in human diet 8

2.1.6.1.1 Raw cassava $\quad 8$ 
2.1.6.1.2 Cooked cassava $\quad 8$

2.1.6.1.3 Dried cassava/Cassava chips 9

2.1.6.1.4 Cassava flour 9

2.1.6.1.5 Cassava starch 9

2.1.6.1.6 Gari 10

2.1.6.1.7 Cassava fritters/tortitas 10

2.1.6.1.8 Cassava rice (Landang) 11

2.1.6.1.9 Monosodium glutamate (MSG) 11

2.1.6.1.10 Cassava pastes 11

$\begin{array}{lll}2.1 .6 .1 .11 & \text { Sago } & 12\end{array}$

2.1.6.2 Cassava in animal feed 12

2.1.6.2.1 Raw roots 12

2.1.6.2.2 Dried cassava/Cassava chips 12

$\begin{array}{lll}2.1 .6 .2 .3 & \text { Gaplek } & 12\end{array}$

2.1.7 Toxicity of cassava 12

2.1.8 Acute cyanide intoxications 14

$\begin{array}{ll}2.1 .9 \text { Detoxification of cyanide } & 14\end{array}$

2.1.10 Effect of processing on cyanide content of cassava products 15

$\begin{array}{lll}2.1 .10 .1 & \text { Peeling } & 15\end{array}$

2.1.10.2 Steeping (Leaching in water) 15

2.1.10.3 Soaking (Fermenting) in water 15

2.1.10.4 Drying 16

$\begin{array}{lll}2.1 .10 .5 & \text { Boiling } & 17\end{array}$

$\begin{array}{lll}2.2 & \text { Bakery products } & 17\end{array}$

$\begin{array}{lll}2.2 .1 & \text { Baking } & 17\end{array}$

$\begin{array}{lll}2.2 .2 \text { Biscuit } & 18\end{array}$

$\begin{array}{lll}2.2 .3 \text { Cakes } & 19\end{array}$

$\begin{array}{lll}2.2 .4 \text { Bread } & 20\end{array}$

2.2.4.1 Raw materials for bread 20

2.2.4.2 Influence of flour proteins on bread 21

2.2.4.3 Bread manufacture 22 
2.2.5 Packaging and storage of baked goods 23

$\begin{array}{lll}2.3 & \text { Sensory evaluation } & 23\end{array}$

$\begin{array}{lll}2.4 & \text { Shelf life of a food } & 23\end{array}$

$\begin{array}{lll}\text { CHAPTER } 3 & \mathbf{2 4}\end{array}$

MATERIALS AND METHODOLOGY 24

3.1 Location 24

3.2 Preliminary market survey 24

$\begin{array}{lll}3.2 .1 & \text { Materials } & 24\end{array}$

$\begin{array}{lll}3.2 .2 & \text { Methodology } & 24\end{array}$

3.3 Manufacture of cassava flour 25

$\begin{array}{lll}3.3 .1 & \text { Materials } & 25\end{array}$

$\begin{array}{ll}\text { 3.3.2 Methodology } 25 & 25\end{array}$

$3.4 \quad$ Formula development and sample preparation $\quad 27$

$\begin{array}{lll}3.4 .1 & \text { Materials } & 27\end{array}$

$\begin{array}{lll}3.4 .2 & \text { Methodology } & 28\end{array}$

3.5 Sensory evaluation on products 33

3.5.1 Materials 33

3.5.2 Methodology 33

3.5.2.1 Sensory evaluation on products 33

3.5.2.2 Sensory evaluation on cassava biscuits $\quad 34$

3.5.2.3 Sensory evaluation on cassava cake $\quad 34$

3.5.2.4 Sensory evaluation on cassava bread $\quad 34$

3.6 Proximate Analysis $\quad 35$

3.6.1 Determination of moisture 35

$\begin{array}{ll}\text { 3.6.1.1 Materials } & 35\end{array}$ 
3.6.1.2 Methodology 35

3.6.2 Determination of total fat 36

3.6.2.1 Materials 36

3.6.2.2 Methodology 36

3.6.3 Determination of crude protein 37

$\begin{array}{ll}\text { 3.6.3.1 Materials } & 37\end{array}$

3.6.3.2 Methodology 38

3.6.4 Determination of crude fibre 38

3.6.4.1 Materials 38

3.6.4.2 Methodology 39

3.6.5 Determination of total ash $\quad 40$

$\begin{array}{ll}\text { 3.6.5.1 Materials } & 40\end{array}$

3.6.5.2 Methodology $\quad 40$

3.7 Shelf life evaluation on cassava flour 41

3.7.1 Total plate count 41

3.7.1.1 Materials 41

3.7.1.2 Methodology $\quad 42$

3.7.2 Sensory evaluation 43

3.7.2.1 Materials 43

3.7.2.2 Methodology 43

$\begin{array}{llr}\text { CHAPTER } 4 & 44\end{array}$

RESULTS AND DISCUSSION 44

4.1 Preliminary market survey 44

4.1.1 Results 44

4.1.2 Discussion 46

4.2 Manufacture of cassava flour 46

$\begin{array}{lll}4.2 .1 & \text { Results } & 46\end{array}$

$\begin{array}{lll}4.2 .2 & \text { Discussion } & 47\end{array}$

$\begin{array}{lll}4.3 & \text { Sensory evaluation } & 49\end{array}$ 
4.3.1 Results 49

4.3.1.1 Sensory evaluation on cassava biscuit 49

4.3.1.2 Sensory evaluation on cassava cake $\quad 49$

4.3.1.3 Sensory evaluation on cassava bread $\quad 50$

$\begin{array}{lll}\text { 4.3.2 Discussion } & 51\end{array}$

4.3.2.1 Sensory evaluation $\quad 51$

4.3.2.2 Sensory evaluation on cassava biscuit 52

4.3.2.3 Sensory evaluation on cassava cake $\quad 52$

4.3.2.4 Sensory evaluation on cassava bread 53

$4.4 \quad$ Formula development 53

4.4.1 Results 53

4.4.1.1 Cassava biscuit 53

4.4.1.2 Cassava cake $\quad 54$

4.4.1.3 Cassava bread $\quad 55$

4.4.2 Discussion $\quad 57$

$\begin{array}{llr}4.5 & \text { Proximate analysis } & 59\end{array}$

4.5.1 Results $\quad 59$

$\begin{array}{lll}\text { 4.5.2 Discussion } & 59\end{array}$

4.6 Shelf life evaluation on cassava flour $\quad 60$

$\begin{array}{lll}4.6 .1 & \text { Results } & 60\end{array}$

$\begin{array}{ll}\text { 4.6.1.1 Total plate count } & 60\end{array}$

$\begin{array}{ll}\text { 4.6.1.2 Sensory evaluation } & 60\end{array}$

$\begin{array}{ll}\text { 4.6.2 Discussion } & 60\end{array}$

4.6.2.1 Total plate count $\quad 60$

$\begin{array}{ll}\text { 4.6.2.2 Sensory evaluation } & 62\end{array}$

$\begin{array}{lll}\text { CHAPTER } 5 & 63\end{array}$

CONCLUSIONS AND RECOMMENDATIONS

$\begin{array}{lll}5.1 & \text { Conclusions } & \cdot\end{array}$

$\begin{array}{lll}5.2 & \text { Recommendations } & 63\end{array}$ 
Appendix 1

Appendix 2

Appendix 3

Appendix 4

Appendix 5

Appendix 6

72

Appendix 7

76

Appendix 8

Appendix 9

82

Appendix 10

83 


\section{List of tables}

2.1 Nutrient composition of different parts of cassava plant 6

$\begin{array}{lll}2.2 & \text { Nutrients in cassava roots compared with other food products } & 7\end{array}$

$\begin{array}{lll}2.3 & \text { Vitamins in cassava roots compared with other food products } & 8\end{array}$

$\begin{array}{lll}2.4 & \text { A guide to acute toxicity } & 14\end{array}$

2.5 Effects of soaking on the HCN content of bitter cassava roots 16

$\begin{array}{lll}2.6 & \text { Oven temperatures for baking } & 17\end{array}$

3.1 Sample preparation for cassava biscuit 28

$\begin{array}{lll}3.2 & \text { Sample preparation for cassava cake } & 29\end{array}$

$\begin{array}{lll}3.3 & \text { Sample preparation for cassava bread } & 29\end{array}$

4.1 Ranked characteristics according to consumer preference level 45

4.2 Modified formula for cassava biscuit $\quad 54$

4.3 Modified formula for cassava cake $\quad 54$

4.4 Modified formula for cassava bread 55

$\begin{array}{lll}4.5 & \text { Results of proximate analysis } & 59\end{array}$

$\begin{array}{lll}4.6 & \text { Results of total plate count }\end{array}$ 


\section{List of figures}

2.1 Transformation of linamarin in to cyanide 13

3.1 Process flow of cassava flour manufacturing 26

3.2 Process flow of cassava biscuit manufacturing 30

3.3 Process flow of cassava cake manufacturing 31

3.4 Process flow of cassava bread manufacturing 32

4.1 Consumer preference on cassava flour based bakery products 44

4.2 Preference level for cassava flour based bakery products 44

4.3 Main characteristic expected to have on cassava flavour based product 45

4.4 Preferred nutrient for the incorporation of cassava based products 45

4.5 Average ranks for cassava biscuits 49

4.6 Average ranks for cassava cakes 50

$\begin{array}{ll}4.7 & \text { Average ranks for cassava bread } \\ \end{array}$ 


\section{List of plates}

4.1 Raw and peeled cassava tubers with processed cassava flour 46

$\begin{array}{lll}4.2 & \text { Processed cassava biscuits } & 56\end{array}$

4.3 Processed cassava cake 56

$\begin{array}{lll}4.4 & \text { Processed cassava bread } & 57\end{array}$ 


\section{Acknowledgement}

I wish to express my deepest gratitude to my supervisors Dr. K.K.D.S. Ranaweera, Co-ordinator /Food Science \& Technology Postgraduate Programmes, Department of Food Science and Technology, University of Sri Jayewardenepura and Prof. A. Bamunuarachchi, Professor of Applied Chemistry, Department of Food Science and Technology, University of Sri Jayewardenepura for their guidance, supervision and encouragement to make this study a success.

I am heavily indebted to all laboratory staff members of the Department of Food Science and Technology for their valuable assistance in numerous ways.

I wish to render my sincere gratitude to the officers of the Ministry of Agricultural Development and Agrarian Services, Battaramulla, who gave a significant contribution to a successful completion.

Special thanks to my colleagues for their invaluable helps given me at all the time I needed to make this venture a success. 


\title{
MANUFACTURE AND UTILIZATION OF CASSAVA FLOUR \\ BY
}

\section{UDENI INDIKA KUMARASINGHEARACHCHI}

\begin{abstract}
Cassava (Manihot esculenta, Crantz) also known as Manioc, Mandioca, Tapioca and Yucca is a root crop cultivated in tropical and sub tropical countries including Sri Lanka. Its tuberous root is the most important part as the food value of it lies in high starch content. The products derived from Cassava are high-energy foods of excellent quality. However, Cassava is a relatively neglected tuber crop and it is processed only in to traditional food preparations without introducing any locally modified processing methods. In order to popularise and maximise the Cassava consumption, a study was carried out to develop value added Cassava flour based bakery products (Biscuit, cake and bread). In this regard, Cassava flour was manufactured using several unit operations. The processed flour was analysed for the nutritional composition and for the shelf life. By carrying out a preliminary market survey, consumer preferences on Cassava flour based bakery products were obtained. In order to select the most preferred sample for further modification, different formula of Cassava based bakery products were developed to produce to the sensory panel for evaluation. Using $1 \mathrm{~kg}$ of fresh Cassava tubers, $300 \mathrm{~g}$ of white coloured, fine powder of Cassava flour could be obtained. Utilizing the processed flour, consumer acceptable $100 \%$ Cassava flour biscuit was formulated incorporating Mung bean (Vigna radiata). Consumer preferred cake product was processed using formulated composite flour of $75 \%$ Cassava and $25 \%$ Rice (Oryza sativa). Bread of acceptable quality was obtained using $30 \%$ Cassava flour. Cassava flour still remained safe from microbial growth after three months storage. Sensory characteristics were comparable for $100 \%$ Cassava biscuits processed using fresh and three months stored Cassava flour.
\end{abstract}

